\title{
Brazilian Distribution of Amblyomma varium Koch, 1844 (Acari: Ixodidae), a Common Parasite of Sloths (Mammalia: Xenarthra)
}

\author{
Sandro Marques, Darci Moraes Barros-Battesti ${ }^{+}$, João Luiz Horacio Faccini* , \\ Valeria Castilho Onofrio
}

Laboratório de Parasitologia, Instituto Butantan, Av. Vital Brasil 1500, 05503-900 São Paulo, SP, Brasil *Departamento de
Parasitologia Animal, Instituto de Veterinária, Universidade Federal Rural do Rio de Janeiro, Seropédica, RJ, Brasil

Amblyomma varium, commonly known in Brazil as the "carrapato-gigante-da-preguiça" (sloth's giant tick) is found from southern Central America to Argentina. The present study adds information on the geographical distribution of A. varium, as well as on their hosts, based on material deposited in the main Brazilian collections and on the available literature. Eighty-two vials, containing 191 adult specimens, deposited in five Acari collections between 1930 and 2001, were examined. These vials included data on the host and collection localities. The biology of A. varium is unknown. However it is known that, during the adult stage, the tick presents a high host specificity and is found almost exclusively on the sloths Bradypus tridactylus, B. variegatus, B. torquatus (Bradypodidae), Choloepus hoffmanni and C. didactylus (Megalonychidae). Based on the material examined, the states of Rondonia, Amazonas, Bahia and Alagoas are newly assigned to geographic distribution of A. varium in Brazil.

Key words: Amblyomma varium - Ixodidae - sloth - Brazilian geographic distribution

Species of the genus Amblyomma Koch are among the largest and most ornamented ticks. The genus includes 102 species of which 32 are found in Brazil (Guimarães et al. 2001). Aragão and Fonseca (1961) listed 33 species for the country. However, according to Jones et al. (1972) and Keirans (1992), A. concolor Neumann was synonymized with $A$. auricularium (Conil), a species commonly found on armadillos (Xenarthra: Dasypodidae).

Amblyomma varium Koch, commonly known in Brazil as the "carrapato-gigante-da-preguiça" (sloth's giant tick), is found almost exclusively on mammals from the families Bradypodidae and Magalonychidae (Xenarthra).

Robinson's comments (1926) on the types of A. varium and on the material deposited in some collections are cited bellow:

"The type came from Brazil. Stoll's A. crassipunctatum from Nicaragua, Central America. Neumann (1899, p. 247) records a male from Brazil, Freycinet coll. (Paris Mus.); a male off a sloth, Zoological Gardens, Hamburg (Hamburg Mus.); a male from Pará, Brazil (Trouessart collection); a male (var. albida), Chile, S. America (Berlin Mus.): also (1901, p. 304) a female, Corrientes, Argentine Republic, S. America (Carlos Berg collection): also (1911, p.76) Neumann mentions Bradypus tridactylus L. and $B$. cuculliger Wagl. as hosts, and adds Guiana to the countries of origin".

This study was supported in part by the Fundação de Amparo à Pesquisa do Estado de São Paulo through project Biota-Fapesp no. 99/05446-8 to DMBB.

${ }^{+}$Corresponding author. Fax: +55-11-3726.1505. E-mail: dbattest@usp.br

*Research Fellow CNPq, Brazil

Received 15 May 2002

Accepted 28 August 2002
This same author also examined the material deposited in the Cambridge University collection, from which he gathered the following data:

"Two females of B. tridactylus (Ex. Rothschild coll, N. 253 and 993); a male of B. tridactylus, Condoto, Colombia, S. America, 1913, H.F. Spurrell coll. (N 2618); a male of large cavy, Bonasica, British Guiana, IV 1912 (N 1738); (?) of sloth, Panama, Central America, IV 1911, O. Garlepp coll. (N 2808); a female, of Choloepus hoffmanni, Ancon, Panama, 31.X.1913, S.T. Darling coll. (N 3156)”.

The Cambridge tick collection, initiated by GHF Nuttall in 1904, was donated to the British Museum in 1939. In the beginning of the 80's, all the material, as well as all the type specimens from Nuttall's collection were revised by Keirans (1984). According to Nuttall's collection catalogue (Keirans 1984), vials N 253 and N 999 included other species of ticks but not $A$. varium and vial N 2808 was lost. On the other hand, this author verified that the specimens included in vial N 1738, were not $A$. varium, but $A$. geayi Neumann and $A$. pictum Neumann. The specimens in the vials N 2618, N 3156 to date, are deposited in the US National Tick Collection (USNTC) under the numbers RML 111398 and RML 112019, respectively.

Unfortunately, the male original description made by Koch (1844) is incomplete, lacking data on host and locality.

In Argentina, the distribution range of A. varium comprises the setentrional zone, between northwestern Chaco and the lower northwestern regions of Salta (Boero 1957). As such, the female originally described from Corrientes (Robinson 1926) might be the most southern record for this species.

Fairchild et al. (1966) revised the A. varium material from Panama, including records for this species on $C$. hoffmanni (16 vials, 30 males and 16 females), on $B$. tridactylus (=B. infuscatus) (12 vials, 30 males and 9 females), on unidentified sloth (4 vials, 10 males and 2 fe- 
males), no host (1 vial, 5 males) and one female on a marsupial "Eaton's opossum" (probably Didelphis marsupialis) from Canal Zone, Panama. Although Vargas (1955) included Mexico in the geographical distribution of A. varium, Fairchild et al. (1966) considered this a doubtful record, since sloths of the genera Bradypus and Choloepus, do not occur in Mexican forests.

Jones et al. (1972) studied ticks from 82 localities in Venezuela between 1965 and 1968. However, no A. varium specimen was found on the collected hosts. Nevertheless, these authors referred to one male and one female, collected on B. tridatylus from Rancho Grande (3500 m elev.), on May 5, 1945, and deposited in the "Rocky Mountain Laboratory" collection (RML). This collection was donated to the US National Museum of Natural History (Smithsonian Institution) in 1983 (Durden \& Keirans 1996).

In 1990, all ticks from the Smithsonian Institution were transferred to the Institute of Arthropodology and Parasitology, Georgia University, and incorporated to the USNTC. This collection is, to date, the world's largest tick collection (Durden et al. 1996).

There is a record of A. varium (variety albida) on $B$. tridatylus from Chile by Neumann (1899). However, Chile is outside the distribution range of Bradypodidae (Wilson \& Reeder 1993, Eisenberg \& Redford 1999) and this record of A. varium is questionable. This specimen (a male, ZMB 1054) was deposited in Berlin Museum (Moritz $\&$ Fischer 1981). Neumann was apparently aware of this unusual locality record for $B$. tridactylus because Chile was not included in Neumann (1911), a fact that has been overlooked by several authors (Robinson 1926, Fairchild et al. 1966, Jones et al. 1972). Therefore we consider the presence of $A$. varium in Chile as doubtful.

Other records for this species include Guatemala, Costa Rica, Guiana and Peru (Floch \& Abonnenc 1940, Floch \& Fauran 1959, Jones et al. 1972, Need et al. 1991).

Except for the few observations in Aragão $(1911,1936)$, Robinson (1926), Osorno-Mesa (1940), Boero (1957), Fairchild et al. (1966), Jones et al. (1972), and Sinkoc et al. (1997), nothing is known on the biology and ecology of this tick species.

The present study aims to add new information on the geographical distribution of A. varium in Brazil, as well as on the tick/host relationship, based on material deposited in Brazilian collections and on the available literature.

\section{MATERIALS AND METHODS}

Twenty-two Brazilian institutions that had arthropod collections were contacted. From these, five collections including tick material were examined, since some curators enabled the study by sending the material to the Butantan Institute for identification and data compilation. From the vials, the following data was compiled: number of specimens, host species, locality, including geographical coordinates, collection date and collector.

Sloth distribution range was based on Wetzel (1982), Emmons (1990), Nowak (1991), Wilson and Reeder (1993), and Eisenberg and Redford (1999).

The maps were obtained from the Excel program, Microsoft version 5.0/95.
Material examined

(Curator or person in charge in parenthesis):

IBSP - Acari Collection of the Butantan Institute (Instituto Butantan, São Paulo, SP) (DM Barros-Battesti);

FMVZ/USP-CNC - National Tick Collection (Coleção Nacional de Carrapatos da Faculdade de Medicina Veterinária e Zootecnia da Universidade de São Paulo, São Paulo, SP) (MB Labruna);

MZUSP - Arthropod Collection of the Zoology Museum (Museu de Zoologia da Universidade de São Paulo, São Paulo, SP) (EM Cancello);

INPA - Arthropod Collection of the National Institute of the Amazon Research (Instituto Nacional de Pesquisas da Amazônia, Manaus, AM) (C Magalhães);

MPEG - Arthropod Collection of the Emilio Goeldi Museum (Museu Paraense Emilio Goeldi, Belém, PA) (AY Harada).

\section{RESULTS}

A total of 82 vials, containing 191 A. varium specimens, were examined. The Brazilian distribution of $A$. varium, according to the collection material and literature records, is shown in Fig. 1A.

\section{IBSP - Butantan Institute}

The IBSP collection includes 44 vials with 117 specimens from the states of São Paulo (SP), Rio de Janeiro (RJ), Bahia (BA), Amazonas (AM), and Alagoas (AL) (94 males, 19 females and 4 nymphs).

Municipalities with $A$. varium records: SP - Cubatão ( $23^{\circ} 89^{\prime} \mathrm{S} 46^{\circ} 42^{\prime} \mathrm{W}$ ); Mogi das Cruzes ( $\left.23^{\circ} 52^{\prime} \mathrm{S} 46^{\circ} 18^{\prime} \mathrm{W}\right)$; Praia Grande ( $\left.24^{\circ} 05^{\prime} \mathrm{S} 46^{\circ} 40^{\prime} \mathrm{W}\right)$; São Paulo (23ำ'

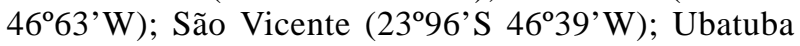
( $23^{\circ} 43^{\prime} \mathrm{S} 45^{\circ} 07^{\prime} \mathrm{W}$ ); RJ - Campos dos Goytacazes (21 ${ }^{\circ} 75^{\prime} \mathrm{S}$ $41^{\circ} 32^{\prime} \mathrm{W}$ ); Casimiro de Abreu (220 $48^{\prime} \mathrm{S} 42^{\circ} 20^{\prime} \mathrm{W}$ ); Campo Grande and Floresta da Tijuca, Rio de Janeiro (22 $90^{\circ} \mathrm{S}$ $\left.43^{\circ} 20^{\prime} \mathrm{W}\right)$; BA - Camacan (15 $\left.41^{\prime} \mathrm{S} 39^{\circ} 49^{\prime} \mathrm{W}\right)$; Ubatã (14²1'S 39 $\left.52^{\prime} \mathrm{W}\right)$.

Host: Bradypus tridactylus Linnaeus - 13 vials with 34 specimens (IBSP 721, 2 males from Cubatão, 15/VIII/ 1934, F Fonseca coll.; IBSP 722, 2 males and 1 female from Cubatão, 15/VIII/1934, F Fonseca coll.; IBSP 798, 3 males from Cubatão, 16/I/1935, F Fonseca coll.; IBSP 799, 3 males from Cubatão, 12/IX/1935, F Fonseca coll.; IBSP 801, 2 males from Cubatão, 08/VII/1935, F Fonseca coll.; IBSP 862, 1 male from São Paulo, 01/X/1934, F Fonseca coll.; IBSP 1090, 1 male from Praia Grande, XI/1935, H. Salibas coll.; IBSP 1190, 1 male with no locality data, 16/XI/1937, coll. unknown; IBSP 1225, 3 males from Ubatuba, 27/XII/ 1937, coll. unknown; IBSP 4902, 7 males and 1 female, locality unknown, 22/XII/1952, Emilio Guerra coll.; IBSP 4969, 3 males and 1 female from São Vicente, 09/VI/1954, Firmino coll.; IBSP 4988, 1 male, locality unknown, 24/II/ 1955, coll. unknown; IBSP 7126, 1 male and 1 female from Floresta da Tijuca, Rio de Janeiro, 09/III/2001, Lilian MQ Lima coll.).

Host: Bradypus variegatus Schinz - 8 vials with 20 specimens (IBSP 6848, 2 males and 1 female from Parque Morumbi, São Paulo, 14/IV/1998, A Joppert coll.; IBSP 6916, 1 female from Parque Morumbi, São Paulo, 14/IX/ 1998, A Joppert coll.; IBSP 7072, 7 males and 1 female, 
locality unknown, 06/III/2001, A Joppert coll.; IBSP 7075, 2 females from Parque Alfredo Volpi, São Paulo, 12/VII/ 2000, A Joppert coll.; IBSP 7076, 1 female from Parque Alfredo Volpi, São Paulo, 12/VII/2000, A Joppert coll.; IBSP 7077, 1 female from Parque Alfredo Volpi, São Paulo, 12/ VII/2000, A Joppert coll.; IBSP 7309, 1 female, locality unknown, 06/III/2001, A Joppert coll.; IBSP 7166, 2 males
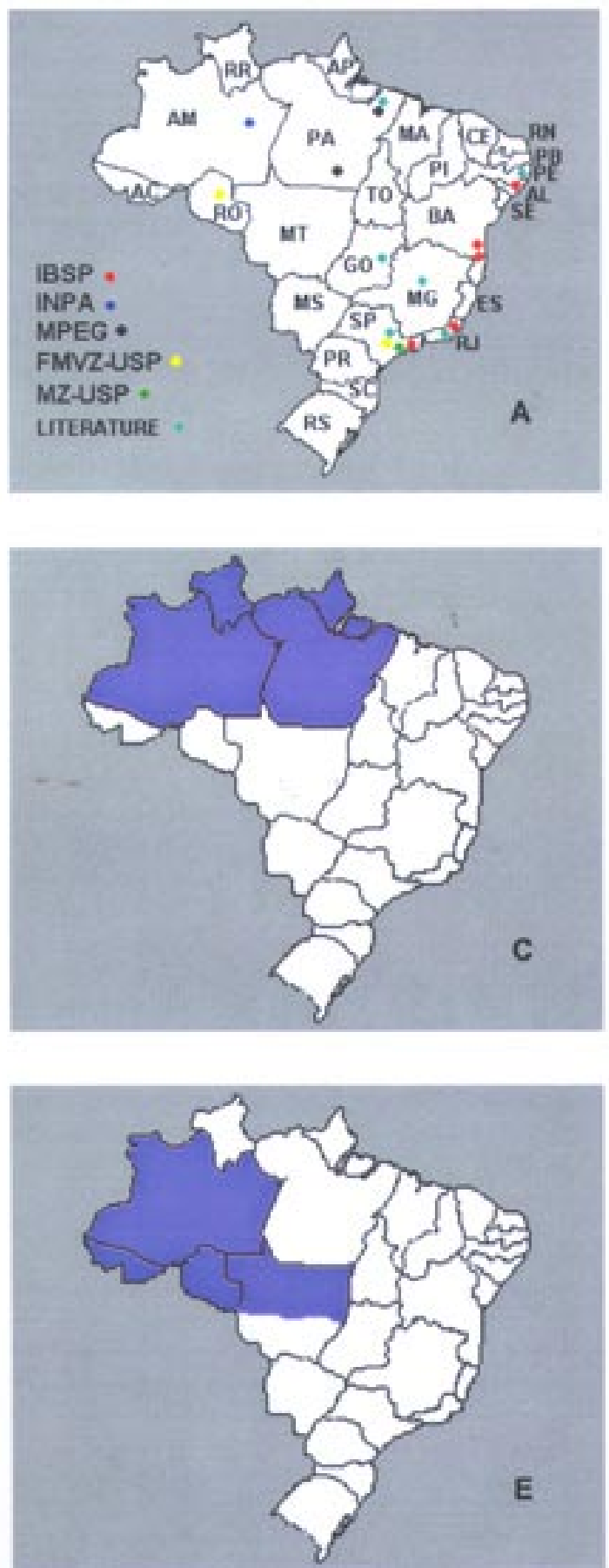

and 1 female from Parque Alfredo Volpi, São Paulo, 12/VII/ 2000, A Joppert coll.).

Host: Bradypus torquatus Illiger - 13 vials with 45 specimens (IBSP-7071, 1 male and 1 female from Ubatã, 30/VII/2000, A Joppert coll.; IBSP 7074, 2 males from Camacan, 27/VII/2000, A Joppert coll.; IBSP 7082, 1 male from Reserva Biológica Poço das Antas, Casimiro de
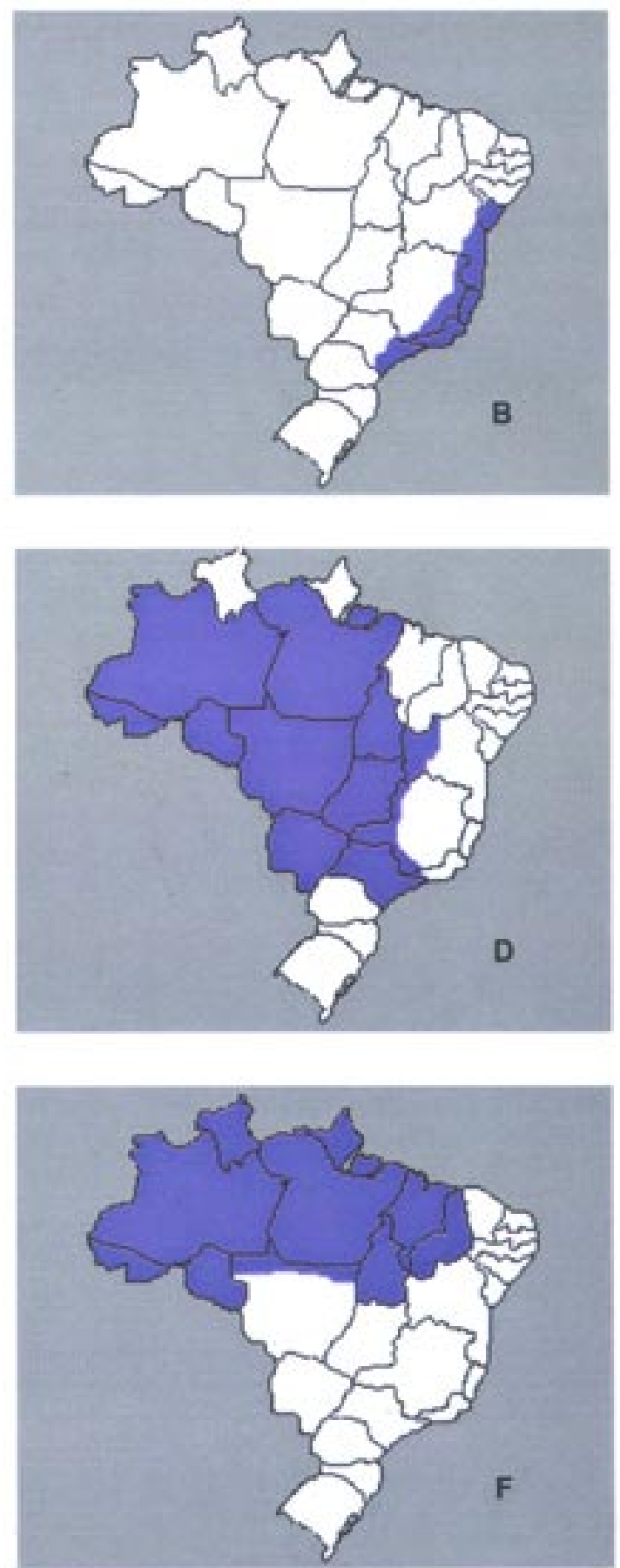

Fig. 1: Brazilian distribution range of Amblyomma varium and sloths, according to collections material and literature. A: A. varium; B: Bradypus torquatus; C: B. tridactylus; D: B. variegatus; E: Choloepus hofmanni; F: C. didactylus. Key to States of Brazil: $\mathrm{AC}=\mathrm{Acre}, \mathrm{AL}$ $=$ Alagoas, $\mathrm{AM}=$ Amazonas, $\mathrm{AP}=$ Amapá, $\mathrm{BA}=$ Bahia, $\mathrm{CE}=$ Ceará, $\mathrm{ES}=$ Espírito Santo, $\mathrm{GO}=$ Goiás, $\mathrm{MA}=$ Maranhão, $\mathrm{MG}=\mathrm{Minas}$ Gerais, MS = Mato Grosso do Sul, MT = Mato Grosso, PA = Pará, PB = Paraíba, PE = Pernambuco, PI = Piauí, PR = Paraná, RJ = Rio de Janeiro, $\mathrm{RN}=$ Rio Grande do Norte, $\mathrm{RO}=$ Rondônia, $\mathrm{RR}=$ Roraima, $\mathrm{RS}=$ Rio Grande do Sul, $\mathrm{SC}=$ Santa Catarina, $\mathrm{SE}=\mathrm{Sergipe} ; \mathrm{SP}=\mathrm{São}$ Paulo, $\mathrm{TO}$ $=$ Tocantins 
Abreu, 1985, coll. unknown; IBSP 7083, 8 males and 1 nymph from Reserva Biológica Poço das Antas, Casimiro de Abreu, 1985, coll. unknown; IBSP 7084, 2 males from Reserva Biológica Poço das Antas, Casimiro de Abreu, 1986, coll. unknown; IBSP 7085, 4 males from Reserva Biológica Poço das Antas, Casimiro de Abreu, 1986, coll. unknown; IBSP 7086, 1 female from Reserva Biológica Poço das Antas, Casimiro de Abreu, 1986, coll. unknown; IBSP 7087, 5 males from Reserva Biológica Poço das Antas, Casimiro de Abreu, 1985, coll. unknown; IBSP 7088, 1 female from Reserva Biológica Poço das Antas, Casimiro de Abreu, 1985, coll. unknown; IBSP 7089, 3 males from Reserva Biológica Poço das Antas, Casimiro de Abreu, 1985, coll. unknown; IBSP 7090, 4 males from Campo Grande, Rio de Janeiro, 1984, coll. unknown; IBSP 7093, 4 males, 1 female and 3 nymphs from Reserva Biológica Poço das Antas, Casimiro de Abreu, 1984, coll. unknown; IBSP 7094, 4 males from Campos dos Goytacazes, 24/V/1982, SM Vaz coll.).

Host: Choloepus hoffmanni Peter - 1 vial with 5 specimens (IBSP-1174, 5 males, locality unknown, from the State of Amazonas, 01/XI/1937, P Savoya coll.).

Host: sloth -6 vials with 10 specimens (IBSP 800, 1 male from São Paulo, 21/VIII/1935, F Fonseca coll.; IBSP 1489, 2 males, locality unknown, 10/IX/1938, coll. unknown; IBSP 3992b, 1 male, locality unknown, 06/VII/1956, I Sherlock coll.; IBSP 4280, 4 males from Mogi das Cruzes, 03/II/1942, Dagoberto Pinto coll.; IBSP 5929, 1 female from Rio de Janeiro, 22/X/1958, H Sick coll.; IBSP 7078, 1 female, locality unknown, from the State of Alagoas, 2000, IBAMA coll. donated by JVL Firmino).

Undetermined host -3 vials with 3 specimens (IBSP 1275, 1 male, locality coll. unknown, donated by A Prado in 1914; IBSP 4501, 1 male from Northeast, 12/XII/1951, Oliveira Lima coll.; IBSP 7121, 1 female, locality unknown, 23/IX/1942, coll. unknown).

FMVZ/USP-CNC National Tick Collection

The FMVZ/USP-CNC includes 6 vials with 9 specimens (4 males and 5 females) from the states of São Paulo (SP) and Rondônia (RO).

Municipalities with A. varium records: SP - São

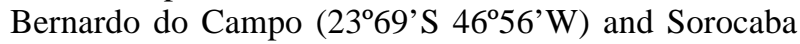

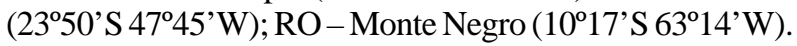

Host: $B$. tridactylus -2 vials with 2 specimens (FMVZ/ USP-CNC 282, 1 male from São Bernardo do Campo Zoological Gardens, XI/1999, MB Labruna coll.; FMVZ/USPCNC 293, 1 male from the same locality, 28/IV/2000, MB Labruna coll.).

Host: $B$. variegatus -1 vial with 4 specimens (FMVZ/ USP-CNC 497, 2 males and 2 females from Sorocaba Zoological Gardens, 08/VI/2001, MB Labruna coll.).

Host: Choloepus sp. - 1 vial with 1 specimen (FMVZ/ USP-CNC 562, 1 male from Monte Negro, 10/VIII/2001, MB Labruna coll.).

Host: sloth - 1 vial with 1 specimen (FMVZ/USP-CNC 269, 1 female from Sorocaba Zoological Gardens, X/1999, MB Labruna coll.).

Free in the environment -1 specimen (FMVZ/USPCNC 540, 1 male from Monte Negro, 19/VI/2001, MB Labruna coll.).
The female from vial FMVZ/USP-CNC 269 was collected alive. It weighted $4100 \mathrm{mg}$, and layed $2100 \mathrm{mg}$ of eggs in the laboratory. The male from vial FMVZ/USPCNC 282 was collected as an engorged nymph that posteriorly molted in the laboratory and the male from vial FMZV/USP-CNC 540 was collected as a nymph, by dragsampling on the vegetation. This nymph molted into a male after feeding on a rabbit (MB Labruna, personal communication).

MZUSP - Zoology Museum of the Universidade de São Paulo

The MZUSP collection includes only one vial with two specimens.

Host: sloth - A vial with two specimens from Caraguatatuba (SP) (23⒍' $\left.\mathrm{S} 45^{\circ} 41^{\prime} \mathrm{W}\right)$ (MZUSP 17067, 2 males, 1957, coll. unknown).

INPA - National Institute of the Amazon Research

The INPA collection includes 26 vials with 38 specimens (32 males and 6 females) identified by JE Keirans from the Georgia University, Statesboro, GA, USA. All vials are from Manaus $\left(03^{\circ} 10^{\prime} S 60^{\circ} 02^{\prime} \mathrm{W}\right)$, State of Amazonas (AM).

Host: B. tridactylus -23 vials with 33 specimens (RML 109171, 1 male, 1977, J Adis coll.; RML 109179, 1 male, 1977, J Adis coll.; RML 112755, 1 male, 15/V/1978; RML 112769, 1 male, 26/IV/1978, J Waage coll.; RML 112782, 1 male, 31/V/1978, Robin C Best coll.; RML 112792, 2 females, 31/V/1978, Robin C Best coll.; RML 112801, 2 males, 28/VIII/1978, Robin C Best coll.; RML 112863, 1 female, 12/X/1977, Robin C Best coll.; RML 112884, 2 females, 26/ III/1978, Robin C Best coll.; RML 112907, 1 male, 31/V/ 1978, Robin C Best coll.; RML 112920, 1 male, 10/IX/1977, Jack Hayes coll.; RML 112932, 1 male, 29/I/1979, Robin C Best coll.; RML 112935, 1 male, 25/VI/1978, Robin C Best coll.; RML 112954, 1 male, 19/IX/1977, Robin C Best coll.; RML 112967, 2 males, 27/III/1976, Robin C Best coll.; RML 112970, 4 males, 5-7/XII/1978, Daniel coll.; RML 112996, 1 male, 12/II/1978, Robin C Best coll.; RML 112999, 4 males, 26/III/1978, Robin C Best coll.; RML 113115, 1 female, 16/ II/1978, Robin C Best coll.; RML 113126, 1 male, 10/VII/ 1979, Robin C Best coll.; RML 113147, 1 male, 10/V/1979, Robin C Best coll.; RML 113163, 1 male, 15/X/1977, Robin C Best coll.; RML 113169, 1 male, 28/V/1979, Robin C Best coll.).

Host: $C$. didactylus Linnaeus -2 vials with 4 specimens (RML 112799, 1 male, 11/IV/1979, Robin C Best coll.; RML 112866, 3 males, 01/II/1979, Robin C Best coll.).

Host: sloth - 1 vial with 1 specimen (RML 112968, 1 male, 24/IV/1978, Robin C Best coll.).

\section{MPEG - Emilio Goeldi Museum}

The MPEG collection includes 5 vials with 25 specimens ( 21 males and 4 females) from Jacundá $\left(04^{\circ} 45^{\prime} \mathrm{S}\right.$ $\left.49^{\circ} 11^{\prime} \mathrm{W}\right)$, Belém ( $\left.01^{\circ} 45^{\prime} \mathrm{S} 48^{\circ} 50^{\prime} \mathrm{W}\right)$ and Parauepebas (06 $\left.06^{\prime} \mathrm{S} 49^{\circ} 90^{\prime} \mathrm{W}\right)$, State of Pará (PA).

Host: sloth -3 vials with 4 specimens (MPEG $1 b, 1$ male from margem direita do Rio Tocantins, Jacundá, 12/ V/1984, WL Overal, coll.; MPEG 3, 2 females from parque of the Museum Paraense Emilio Goeldi, Belém, 13/III/1984, A Muniz coll.; MPEG 37, 1 female from of the Museum Paraense Emilio Goeldi, 6/III/1992, José Arnaldo coll.). 
Host: Three-toed sloth -1 vial with 20 specimens (MPEG 24a, 20 males from Serra Norte, Parauepebas, 5/ VII/1983, RB Neto coll.).

Undetermined host - 1 vial with 1 specimen (MPEG 4, 1 female from Parque of the Museum Paraense Emilio Goeldi, Belém, 13/VII/1984, A Muniz coll.).

\section{Literature records}

Host: B. tridactylus - A. varium males and females from Rio de Janeiro, Xerém and Iguassú (RJ), Lassance and Teixeira Soares (MG), Brasília (Distrito Federal), Belém (PA) and São Paulo (SP) (Aragão 1911, 1936); males from the Parque Zoobotânico of the Emilio Goeldi Museum, Belém (PA) (Serra-Freire et al. 1995); and one female recorded by Amorim and Serra-Freire (1996) from the Fundação RIO/ZOO, Rio de Janeiro (RJ).

Host: B. variegatus - 5 males and 4 females of $A$. varium from Ilha de Itamaracá (PE). According to Sinkoc et al. (1997), one of the females was completely engorged and weighed $3.92 \mathrm{~g}$.

Distribution range for sloths in the national territory

Bradypodidae family - The "preguiça-de-coleira" (maned three-toed sloth), B. torquatus (Fig. 1B) occurs in the coastal Atlantic Forest, from south Alagoas to southern São Paulo states. The "preguiça-de-bentinho" (palethroated three-toed sloth), B. tridactylus (Fig. 1C) is just found in the northern region, from the proximities of the rivers Negro, Amazonas and Solimões to Belém (PA), occurring in Amapá (AP), Amazonas (AM), Pará, and Roraima (RR) states. The "preguiça-ai-ai" (brown-throated three-toed sloth), B. variegatus (Fig. 1D), is well distributed within the country, mainly in the Center-west region, with the exception of the states of Amapá, Roraima, Maranhão (MA), Piauí (PI), Ceará (CE), Rio Grande do Norte (RN), Paraíba (PB), Pernambuco (PE), Alagoas (AL), Sergipe (SE), eastern Bahia (BA) and Minas Gerais (MG), Espírito Santo (ES), and southern region (Paraná, Santa Catarina, and Rio Grande do Sul).

Megalonychidae family - The species C. hoffmanni "unau" or "preguiça real" (Hoffmann's two-toed sloth) (Fig. 1E) is distributed in northern Mato Grosso (MT), Rondônia (RO), Acre (AC), and Amazonas states, while C. didactylus "preguiça real" (southern two-toed sloth) (Fig. 1F) is found in the northern region forests, mainly in the proximities of the rivers Amazonas and Solimões (Amazon Basin). Its distribution includes Acre, Rondônia, Roraima, Amapá, Amazonas, Pará, Maranhão, Piauí, Tocantins (TO), and possibly the northern Mato Grosso states.

\section{DISCUSSION}

The states of Rondônia, Amazonas, Alagoas and Bahia are newly assigned to the distribution range of $A$. varium. For the remaining Brazilian states, where $A$. varium was not reported (Fig. 1A), no specimen was found in the examined collections, neither are there any records for this species in the available literature.

Currently sloths do not occur in southern Brazil (Fig. 1B-F) (Wetzel 1982, Emmons 1990, Nowak 1991, Wilson \& Reeder 1993, Eisenberg \& Redford 1999). However they existed in this region in the first half of 20th century (Vieira
1955, Cimardi 1996). Considering the A. varium presents high host specificity, it is probable this tick was not observed in the Southern region due to a complete absence of their hosts in the area.

Although B. tridactylus is restricted to the states of Roraima, Amapá, Amazonas, and Pará (Fig. 1C), several A. varium specimens were collected on this host in the Southeastern region, according to the data labels of the examined material and in the Central-western region (Aragão 1936). Disconsidering the zoological records, it is possible that there was a misidentification of the host, since only $B$. torquatus and B. variegatus are recorded for these regions (Fig. 1B, D). The species B. variegatus is widely distributed throughout Southeastern Brazil, while $B$. torquatus is just restricted to the eastern coastal areas. Despite the existence of several vials of $A$. varium collected on B. variegatus, deposited in the IBSP and FMVZ/ USP-CNC collections, only one record was found in the available literature, from Ilha de Itamaracá, State of Pernambuco (Sinkoc et al. 1997).

Considering the distribution of the sloths, several specimens of $A$. varium from the Southeastern region, collected on $B$. tridactylus, especially those from the coastal areas of the State of São Paulo, could have been collected on B. variegatus (Fig. 1D) or even on $B$. torquatus (Fig. 1B). This is even more true for those specimens collected in the State of Rio de Janeiro where only these two species of sloth are recorded.

Concerning the biology of A. varium, some egg batches from engorged females collected in parks in the city of São Paulo were maintained in incubators at $27^{\circ} \mathrm{C}$ and $90-95 \%$ humidity. Nevertheless, most eggs were nonviable and those emerging larvae died a few days later. Possibly, higher humidity acts as a limiting factor, as observed for A. longirostre Koch (DM Barros-Battesti, unpublished data), as well as A. aureolatum (Pallas) under laboratory conditions (MB Labruna, pers. commun.), and in the natural environment (M Arzua, pers. commun.). The A. varium female, when engorged, is one of the largest Amblyomma species and lays up to 15,000 eggs (Aragão 1936).

Although the vial contains no information on host, collection locality and collector, the female deposited in IBSP 7121, is the largest specimen of the IBSP collection. The information on the identification label read that, at the time of collection, the specimen was $30 \mathrm{~mm}$ long X 25 $\mathrm{mm}$ wide $\mathrm{X} 18 \mathrm{~mm}$ high and weighed $8.6 \mathrm{~g}$. Together with this female, other specimens almost as large and as heavy are deposited in IBSP 722, IBSP 6916 and IBSP 7078.

The USNTC from the Arthropodology and Parasitology Institute at the Georgia University includes a female (RML 112019 from Nuttall collection N 3156) that before laying 9,759 eggs measured 30 X 24 X 15 mm and weighed $5.9 \mathrm{~g}$ (Keirans 1984).

According to Fairchild et al. (1966), two females from Panama, when collected weighed 6.4 g. Aragão (1936) referred to a female measuring $30 \times 26 \mathrm{~mm}$ that was deposited in the Instituto Oswaldo Cruz collection (Fiocruz).

A specimen collected in the French Guiana, measuring 32 X $30 \mathrm{~mm}$ and weighing $7.5 \mathrm{~g}$ (Floch \& Fauran 1958) might be the largest specimen registered to date. However, the specimen from IBSP 7121 seems to be the heaviest. 
In nature, the hosts for $A$. varium larvae are unknown. Except for the one engorged nymph that molted into a male (FMVZ/USP-CNC 282), collected on B. tridactylus in São Bernardo do Campo Zoo (MB Labruna, pers. communicati.) the only other records of nymph parasitism are those from IBSP 7083 and 7093, both collected on $B$. torquatus. Nevertheless, we are not sure these two specimens are indeed $A$. varium nymphs since there is no available identification key for tick nymphs. However, these specimens were collected together with adult specimens of A. varium on hosts that were not infested by any other species of tick.

The collection of a nymph, on vegetation, that engorged on a rabbit (FMVZ/USP-CNC 540) and molted to a male is probably the only case of feeding on a laboratory animal. Nevertheless, the possibility of nymphs infesting other hosts such as small mammals or even birds should not be discarded since little is known on the host parasite relations of this species in nature.

With the exception of probably accidental records of parasitism on a pet dog and on a deer, from Argentina (Boero 1957), on a marsupial from Panama, and on a wild pig from the Peruvian Amazon, Peru (Fairchild et al. 1966), it is suggested that $A$. varium adults are highly specific for sloths.

\section{ACKNOWLEDGEMENTS}

To Adriana Joppert da Silva, from Departamento de Parques e Áreas Verdes da Prefeitura Municipal de São Paulo and João Victor Lima Firmino for donation of the material; Ana Y Harada (MPEG), Augusto L Henriques and Célio Magalhães (INPA), and Ricardo Pinto da Rocha (MZUSP) for material loans; Marcelo B Labruna for the compilation of data from the material deposited in the FMVZ/USP-CNC; Michel Miretzki for the sloths distribution revision, and to the curators/persons in charge from other collections for the supplied information.

\section{REFERENCES}

Amorim M, Serra-Freire NM 1996. Morphological description of tick larval stage (Acari: Ixodidae). 3. Amblyomma varium Koch, 1844. Entomol Vect 6: 75-90.

Aragão HB 1911. Notas sobre Ixodidas brasileiros (Notes sur les Ixodides du Brésil). Mem Inst Oswaldo Cruz 3: 145-195.

Aragão HB 1936. Ixodidas brasileiros e de alguns paizes limitrophes. Mem Inst Oswaldo Cruz 31: 759-844.

Aragão HB, Fonseca F 1961. Notas de Ixodologia. VIII. Lista e chave para os representantes da fauna ixodológica brasileira. Mem Inst Oswaldo Cruz 59: 115-129.

Boero JJ 1957. Las Garrapatas de la República Argentina (Acarina: Ixodoidea), Universidad de Buenos Aires, Buenos Aires, $113 \mathrm{pp}$.

Cimardi AV 1996. Mamíferos de Santa Catarina, FATMA, Florianópolis, 302 pp.

Durden LA, Keirans JE 1996. Nymphs of the Genus Ixodes (Acari: Ixodidae) of the United States: Taxonomy, Identification Key, Distribution, Hosts, and Medical/Veterinary Importance, Entomological Society of America, Lanham, Maryland, 95 pp.

Durden LA, Keirans JE, Oliver Jr JH 1996. The U.S. National tick collection: a vital resource for systematics and human and animal welfare. Am Entomol 42: 239-243.

Eisenberg JF, Redford KH 1999. Mammals of the Neotropics: Ecuador, Peru, Bolivia, Brazil, Vol. 3, The University of Chicago Press, Chicago and London, 609 pp.
Emmons LH 1990. Neotropical Rainforest Mammals: a Field Guide, University of Chicago Press, Chicago, $281 \mathrm{pp}$.

Fairchild GB, Kohls GM, Tipton VJ 1966. The ticks of Panama (Acarina: Ixodoidea). In RL Wenzel, VJ Tipton (eds), Ectoparasites of Panama, Field Museum of Natural History, Chicago, p. 167-219.

Floch H, Abonnenc E 1940. Ixodides de la Guyane Francaise. Publ Inst Pasteur Guy Ter l'Inini (Cayenne) 4: 1-31.

Floch H, Fauran P 1958. Ixodidés de la Guyane et dês Antilles Francaises. Archieves de I'Institut Pasteur de la Guyane Francaise (Publication 446) 19: 1-94.

Floch H, Fauran P 1959. Les Ixodidae du genre Amblyomma en Guyane et aux Antilles Francaise. Acarologia 1: 216-227.

Guimarães JH, Tucci EC, Barros-Battesti DM 2001. Ectoparasitos de Importância Veterinária, Plêiade/Fapesp, São Paulo, $218 \mathrm{pp}$.

Jones EK, Clifford CM, Keirans JE, Kohls GM 1972. The ticks of Venezuela (Acarina: Ixodoidea) with a key to the species of Amblyomma in the western hemisphere. Brigham Young Univ Sci Bull Biol Ser 17: 1-40.

Keirans JE 1984. George Henry Falkiner Nuttall and the Nuttall Tick Catalogue, U. S. Department of Agriculture Miscellaneous Publications, Washington, 1785 pp.

Keirans JE 1992. Systematics of Ixodida (Argasidae, Ixodidae, Nuttalliellidae): an overview and some problems. In B Fivaz, T Petney, I Horak (eds), Tick Vector Biology. Medical and Veterinary Aspects, Springer Verlag, Berlin, p. 1-21.

Koch CL 1844. Systematische Übersicht über die Ordnung der Zecken. Archive fur Naturgeschichte 10: 217-239.

Moritz M, Fischer SC 1981. Die typen der arachnidansammlung des zoologischen museums Berlin. IV. Ixodei. Mitt Zool Mus Berlin 57: 341-364.

Need JT, Dale WE, Keirans JE, Dasch GA 1991. Annotated list of ticks (Acari: Ixodidae, Argasidae) reported in Peru: distribution, hosts, and bibliography. J Med Entomol 28: 590-597.

Neumann LG 1899. Revisión de la famille des Ixodidés. Mém Soc Zool Fr 12: 107-294.

Neumann LG 1911. Ixodidae, Das Tierreich 26, Berlin, 169 pp.

Nowak RM 1991. Walker's Mammals of the World, 5th ed., The Johns Hopkins University Press, Baltimore and London, 642 pp.

Osorno-Mesa E 1940. Las garrapatas de la Republica de Colombia. Revista de la Academia Colombiana de Ciencias Exactas, Físico-Químicas y Naturales 4: 6-24.

Robinson LE 1926. Ticks. A Monograph of the Ixodoidea. Part IV. The Genus Amblyomma, Cambridge University Press, London, 302 pp.

Serra-Freire NM, Amorim M, Peralta ASL, Gazeta GS 1995. Parasitismo simultâneo por Amblyomma varium e A. geayi em B. tridactylus. Arq Soc Zool Bras 16: 21.

Sinkoc AL, Brum JGW, Begrow A, Picanço M 1997. Ocorrência de Amblyomma varium Koch, 1844 em preguiça (Bradypus variegatus) no Estado do Pernambuco, Brasil. Arq Fac Vet UFRGS 25: 105-107.

Vargas L 1955. Relacion del papel patogeno de las garrapatas y lista de las especies mexicanos. Gaceta Med de Mexico 85: 489-502.

Vieira CC 1955. Lista remissiva dos mamíferos do Brasil. Arq Zool Estado São Paulo 8: 1-474.

Wetzel RM 1982. Systematics, distribution, ecology, and conservation of South American edentates. In M Mares, H Genoways (eds), Mammalian Biology in South America, Pymatuning Symposia in Ecology 6, Special Publication Series, Pittsburgh, p. 345-375.

Wilson DE, Reeder DM 1993. Mammals Species of the World: a Taxonomic and Geographic Reference, 2nd ed., Smithsonian Institution Press, Washington and London, 1207 pp. 